(i)

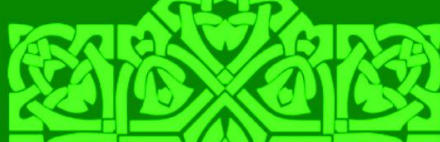
tह

Muhammad Yusuf, Baharuddin, Mardan The Quranic Hermeneutics Approach to Gender Equality in Amina Wadud Muhsin's View

A. Zamakhsyari Baharuddin التظاهر بالشعار ات القومية في شعيرة الحج و العمرة

Andi Muhammad Ridwan, Baso Pallawagau Falsafah Al-Wujudiyyah Al-Sufiyyah: Asluha Al-Dini wa Manqif Al-Ulama Minha

Muhammad Widus Sempo, Norita Binti Md Norwawi, Hasyim Haddade, Yousuf Mahbubul Islam, Noorhayati Binti Hasyim Unbelievers' Mental Model and Behavioural Disorders Based on Their Queries in The Al-Baqarah Chapter

Sri Sunantri, Achmad Abubakar, Kamaluddin Abu Nawas, Firdaus Methodology of Interpretation of Muhammad Amin Al-Syinqiti

Amirullah, Andi Achruh AB. Pasinringi, Rahmawansyah Sahib The Transformation of The Muamalah Fiqh Akad at Saga Abepura-Papua Mall During The Covid 19 Pandemic

Irwan Misbach Siri'Na Pacce Culture in Retailer Based on Islamic Perspective Business Ethics

Abd. Rahman R Family Resilience in Islamic Perspective (A Case Study of Parent and Child Interaction Behavior in The District of Somba Opu Gowa)

Vol. 20 No. $2 / 2020$ 


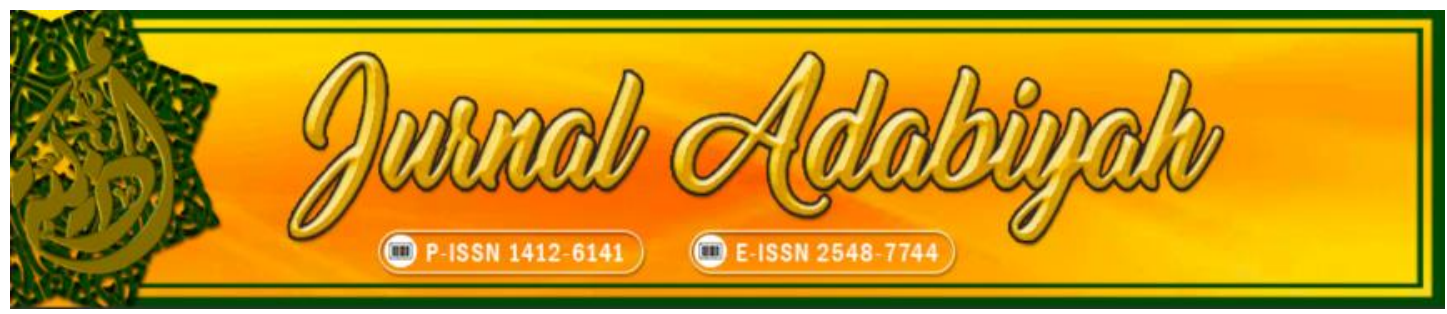

Theme: Islamic Studies

VOLUME 20 NO. 2 DECEMBER 2020

\section{EDITOR-IN-CHIEF}

Barsihannor, Alauddin State Islamic University, Indonesia

\section{INTERNATIONAL EDITORIAL BOARD}

Nuri Emmiyati, Alauddin State Islamic University, Indonesia

Minako Sakai, Australian National University (ANU), Australia

Abd Rauf Muhammad Amin, Fakulti Syariah Kupu SB Brunei Darussalam, Brunei Darussalam

Muhammad Widus Sempo, Universiti Sains Islam Malaysia, Malaysia

Salih Yousif Sharaf Mohamed, Al-Gazera University, Sudan

Aishah Waenaha Waemamah, Academy of Islamic and Arabic Studies Princess of Naradhiwas University - Thailand, Thailand

\section{EXECUTIVE EDITOR}

Umar Thamrin, Alauddin State Islamic University, Indonesia

\section{MANAGING EDITOR}

Nasrum, Alauddin State Islamic University, Indonesia

\section{EDITORS}

Rosmah Tami, Alauddin State Islamic University, Indonesia Haniah Haniah, Alauddin State Islamic University, Indonesia Zaenal Abidin, Alauddin State Islamic University, Indonesia

Awaluddin Syamsu, Universitas Muslim Indonesia

Ahmadi Usman, UIN Syarif Hidayatullah Jakarta, Indonesia

Baso Pallawagau, Alauddin State Islamic University, Indonesia

Muhammad Azwar, UIN Syarif Hidayatullah Jakarta, Indonesia

Muh. Saleh Syamsuri, Alauddin State Islamic University, Indonesia

Andi Satrianingsih, Muhammadiyah University, Indonesia

Syahruni - Junaid, Alauddin State Islamic University, Indonesia

Rabiatul Adawiah, Majene Islamic State College, West Sulawesi, Indonesia, Indonesia

Chusnul Chatimah Asmad, Alauddin State Islamic University, Indonesia

Nur Arifin, Alauddin State Islamic University, Indonesia

\section{IT SUPPORT}

Taufiq Mathar, Alauddin State Islamic University, Indonesia

\section{LANGUAGE ADVISOR}

Kustiwan Syarief, UIN Syarif Hidayatullah Jakarta, Indonesia Muh. Saleh Syamsuri, Alauddin State Islamic University, Indonesia

\section{COVER DESIGNER}

Nur Arifin 


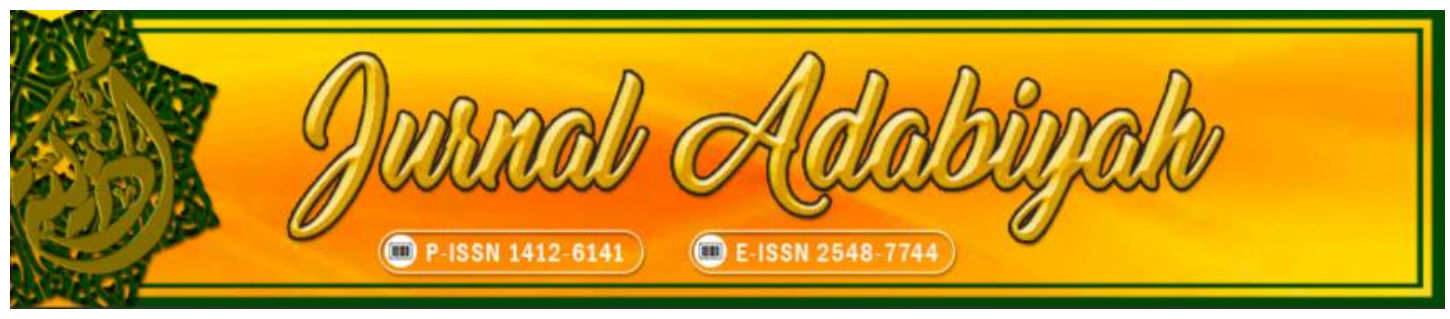

\section{Jurnal Adabiyah:}

This journal receives a national accreditation from Ministry of Research, Technology, and Higher Education Republic of Indonesia, Nomor 10/E/KPT/2019 on April 4, 2019 with the SINTA score: S2.

The Journal has been published by the Faculty of Adab and Humanity of Alauddin State Islamic University, Makassar, since 1997 and has been online since 2016 with the main themes on Humanities and Islamic Studies with the emphasis on interdisciplinary and intertextuality approach.

This journal are published twice a year, on June and December. The themes related to Islamic Studies are textual studies, scriptural traditions, Islamic law, and theology; and those related to Humanities are language, literature, history, and culture.

The journal of Humanities and Islamic Studies will provide the online collection of articles from 1997 up to now. The most updated information can be found on the website. 


\section{Table of Contents}

Muhammad Yusuf, Baharuddin, Mardan

214-237

The Quranic Hermeneutics Approach to Gender Equality in Amina Wadud Muhsin's View

A. Zamakhsyari Baharuddin

التظاهربالشعارات القومية في شعيرة الحج والعمبرة

261-285

Andi Muhammad Ridwan, Baso Pallawagau

Falsafah Al-Wujudiyyah Al-Sufiyyah: Asluha Al-Dini wa Mauqif AlUlama Minha

Muhammad Widus Sempo, Norita Binti Md Norwawi, Hasyim Haddade, Yousuf Mahbubul Islam, Noorhayati Binti Hasyim ................... 286-299 Queries in The Al-Baqarah Chapter

Sri Sunantri, Achmad Abubakar, Kamaluddin Abu Nawas, Firdaus. 300-319 Methodology of Interpretation of Muhammad Amīn Al-Syinqiti

Amirullah, Andi Achruh AB. Pasinringi, Rahmawansyah Sahib

The Transformation of The Muamalah Fiqh Akad at Saga Abepura-Papua Mall During The Covid 19 Pandemic

Irwan Misbach

Siri' Na Pacce Culture in Retailer Based on Islamic Perspective Business Ethics

Abd Rahman R

Family Resilience in Islamic Perspective (A Case Study of Parent and Child Interaction Behavior in The District of Somba Opu Gowa) 


\title{
UNBELIEVERS' MENTAL MODEL AND BEHAVIOURAL DISORDERS BASED ON THEIR QUERIES IN THE AL- BAQARAH CHAPTER
}

\author{
Muhammad Widus Sempo ${ }^{1}$, Norita Binti Md Norwawi ${ }^{2}$, Hasyim Haddade ${ }^{3}$, \\ Yousuf Mahbubul Islam ${ }^{4}$, Noorhayati Binti Hasyim ${ }^{5}$ \\ Universiti Sains Islam Malaysia $^{1,2}$ \\ Alauddin State Islamic University of Makassar, Indonesia ${ }^{3}$ \\ Daffodil Internasional University ${ }^{4}$ \\ Universiti Sains Islam Malaysia ${ }^{5}$ \\ Email: widus81@usim.edu.my ${ }^{1}$, norita@usim.edu.my ${ }^{2}$, hasyim.haddade@uin- \\ alauddin.ac.id ${ }^{3}$, ymislam@daffodilvarsity.edu.bd ${ }^{4}$, drnoorhayati@usim.edu.my $^{5}$
}

\begin{abstract}
Unbelievers historically are the people who rejected the message of Allah revealed to His Prophet Muhammad (Peace be upon Him). The Prophet Muhammad is the Messenger of Allah who fights against idolaters and unbelievers. However, they kept denying the message of Islam and slandering the Prophet Muhammad SAW in many ways they can do. Instead of fully accepting Islam, they rejected the Prophet Muhammad's teaching and caused both physical and psychological torture. The Prophet Muhammad felt hurt due to the mockery and their fabricated question to ridicule him indirectly. Thus, it is very significant to know the character of unbelievers, who they are actually, through analyzing their questions in the al-Baqarah chapter. This study relies on descriptive quantitative methods through the collection of verses related to the question of unbelievers to the prophet Muhammad in the alBaqarah chapter. The study found that unbelievers went astray indicated by the purpose of their questions, which is not for the sake of truth, but to mock the Prophet Muhammad or to look for his fault. So, their question were sometimes illogical, and driven by stubbornness and selfconceit.
\end{abstract}

Keywords: Unbeliever; Behavioural Disorders; al-Baqarah; Query; Exegesis

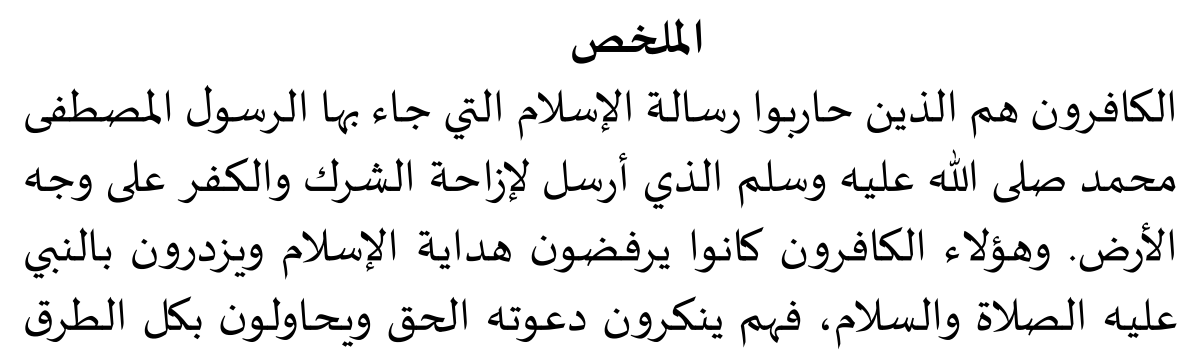


Unbelievers' Mental Model and Behavioural Disorders Based on Their Queries in The Al-

$$
\begin{aligned}
& \text { الفتك به. وقد أثر ذلك في الرسول عليه الصالاة والسام، ولا سيما }
\end{aligned}
$$

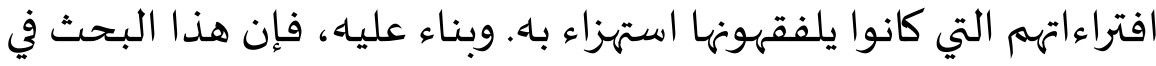

$$
\begin{aligned}
& \text { معدنا يتقصى حقيقة نفس الكفرة وأخلاقهم الرذيلة من خلال أسئلتهم أسته }
\end{aligned}
$$

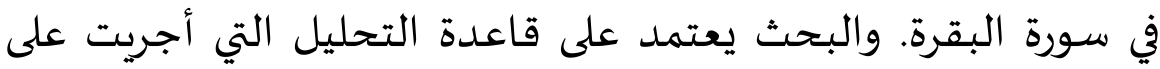

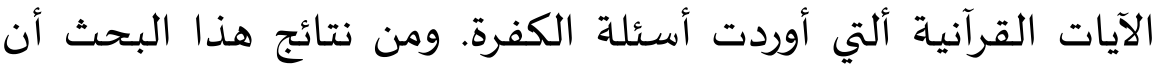

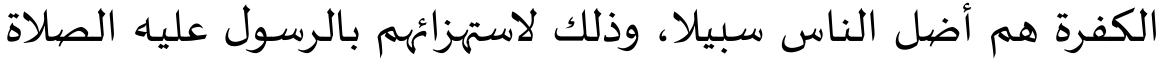

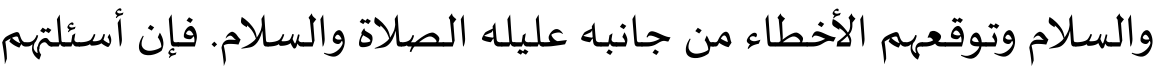

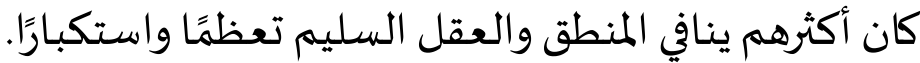

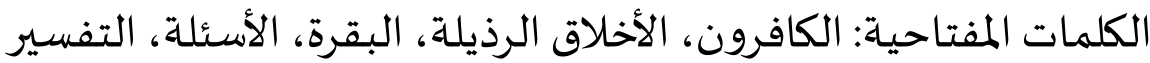

\begin{abstract}
Abstrak
Orang-orang kafir adalah mereka yang menolak risalah Allah SWT melalui Nabi Muhammad SAW yang diutus untuk memerangi kemusyrikan dan kekufuran. Oleh itu, mereka sentiasa menolak hidayah Islam dan memfitnah baginda Nabi SAW secara berterusan. Mereka turut menafikan kebenaran dakwah baginda Nabi SAW dan juga menyiksa baginda sama ada secara fizikal mahupun psikologi. Perasaan baginda Nabi Muhammad terluka karena makian ataupun mereka yang sengaja dibuat-buat untuk untuk mengejek baginda. Oleh itu, artikel ini menyoroti mental dan tingkah laku buruk orang-orang kafir melalui ayat-ayat pertanyaan yang dilontarkan oleh mereka dalam surah al-Baqarah. Kajian ini menggunakan kaedah kuantitatif deskriptif melalui pengumpulan ayatayat tanya oleh orang-orang kafir dalam surah al-Baqarah. Sebagai kesimpulan, orang-orang kafir adalah kumpulan yang sesat dimana pertanyaan mereka bukan untuk mencari kebenaran. Justeru, mereka berpura-pura bertanya untuk menghina baginda Nabi SAW atau mencari kesalahannya. Pertanyaan mereka kebanyakannya adalah tidak logik, bahkan petanyaan mereka mencerminkan sifat angkuh dan ujub.
\end{abstract}

Kata kunci: Orang-Orang Kafir, Tingkah Laku Buruk, Al-Baqarah, Pertanyaan, Tafsir

\title{
A. Introduction
}

There are four community groups at the time of the Prophet Muhammad (peace be upon him) mentioned in the Quran, namely, unbelievers, polytheists, Jews and hypocrites. According to al-Nawawi (1392:2/71), polytheism and disbelief are not different in meaning when referring to disbelief in Allah. In some conditions, the meaning of idolatry is not the same as the polytheism. As for the idolatry meant to associate idols with Allah as the unbelievers of Quraish done in Mekah. Thus, the 
meaning of disbelief is very broad compared to polytheism. ${ }^{1}$ This study cover only unbelievers based on the Ouranic question in the Al-Baqarah chapter.

Mental health includes our emotional, psychological, and social well-being. It affects how we think, feel, and act. It also helps determine how we handle stress, relate to others, and make choices. Mental health is important at every stage of life, from childhood and adolescence through adulthood. ${ }^{2}$

An emotional and behavioural disorder is an emotional disability characterized by the following:

1. An inability to build or maintain satisfactory interpersonal relationships with peers and/or other people in community.

2. An inability to learn which cannot be adequately explained by intellectual, sensory or health factors.

3. A consistent or chronic inappropriate type of behaviour or feelings under normal conditions.

4. A displayed pervasive mood of unhappiness or depression.

5. A displayed tendency to develop physical symptoms, pains or unreasonable fears associated with personal or society problems.

A query comes from the Latin "quaere" which means "to ask, seek, or gain." It is defined as a request for information. Simply put, it is the act of asking a question, one of the procedures in making an inquiry. It is an oral or written request for information on the correctness of certain statements or facts. It is a question that expresses doubt and uncertainty about certain facts that are presented. It is meant to check out and examine the accuracy and truth about people, things, and ideas. It may also be an expression of opposition against something or someone.

This study looks at the mental and the behavioural disorders of unbelievers, based on the Quranic query in the Al-Baqarah chapter.

Al-Baqarah is the name for the second chapter of the Holy al-Quran. This name also mentioned in verse 67 of the surah. Al-Baqarah means a female cow linked with the story of the Israelites (Bani Isrāill). They were asked by God to slaughter the female cow to reveal the mystery of the man killed at the time of Prophet Musa. The method is to hit the bone of a female cow that has been slaughtered into the body of

${ }^{1}$ Al-Nawawi, Yahya bin Sharaf, Sharh al-Nawawi 'Ala Muslim, Vol. 2 (Beirut: Dar Ihyā' alTurāth al- ${ }^{-}$Arabi, 1392 H), p. 71.

${ }^{2}$ Mental Health.gov, What is Mental Health? https://www.mentalhealth.gov/basics/what-ismental-health. Accessed on 30 September 2020.

${ }^{3}$ Council for Ecxeptional Childrem, Behavior Disorders: Definitions, Characteristics \& Related Information. https://community.cec.sped.org/ccbd/about/ebddefintion. Accessed on 28 Sept 2020.

${ }^{4}$ Difference Between.net, Difference Between Onquiry and Query. http://www.differencebetween.net/language/words-language/difference-between-inquiry-and-query/. Accessed on 28 Sept 2020. 
Muhammad Widus Sempo, Norita Binti Md Norwawi, Hasyim Haddade, Yousuf Mahbubul Islam, Noorhayati Binti Hasyim
Unbelievers' Mental Model and Behavioural Disorders Based on Their Queries in The Al-

this man. With God's permission, the body of this corpse will awake for a moment to tell who the real killer is. 5

In addition to the name al-Baqarah, this surah is also known as surah al-Kursi

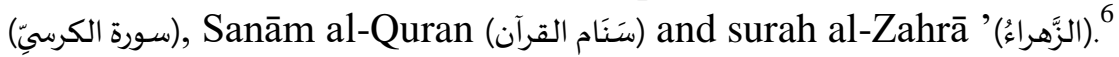

The general purpose behind the Al-Baqarah chapter's revelation divided into two parts:

Part one: To strengthen the glory of Islam and give clear guidelines to human beings about the pure values of Islamic moralitv.

Part two: To explain Islamic law and give guidance to Muslims on the best methods in enhancing their social life in society. ). ${ }^{7}$

\section{B. Research Method}

This study employs the qualitative by exploring the query in the Al-Baqarah chapter related to the unbeliever. The first step is to identify the Qur'anic verses related to the unbeliever in the Al-Baqarah chapter. Next, all of these verses are studied by referring to the definite books of tafsir. Each verse analyzed through the following stages of discussion as follows: First: to identify the model and the purpose of the unbeliever query in the Al-Baqarah chapter. For some instances, the question issued from Allah to test unbeliever.. Second: the Quranic query analyzed very detail based on the Quranic interpretation. Third: to summarize the improper behaviour of the unbelievers based on their query in the Al-Baqarah chapter.

\section{Material of This Study}

Below is the collected verses pertaining the unbeliever's query in the AlBaqarah chapter as follows:

\section{THE FIRST VERSE}

Allah says in the Al-Baqarah chapter, verse 26:

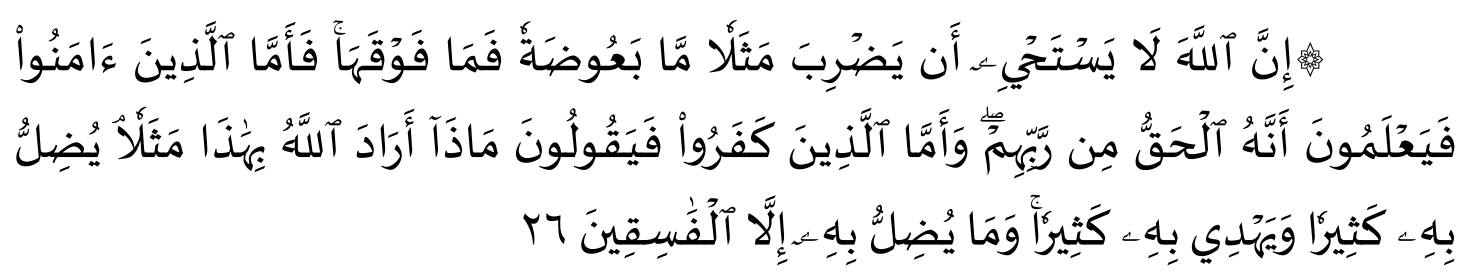

${ }^{5}$ Ibn Kathīr, Ismāēil bin 'Umar, Tafsīr al-Quran al-'Azìm (online tafsir). http://www.qtafsir.com/index.php?option=com_content\&task=view\&id=3137. Accessed on 15 September 2020.

${ }^{6}$ Al-Fayruzabādi, Muhammad bin Ya'qūb, Bașā̄r Dhawi al-Tamyīz fi Lațāif al-Kitāb al- 'Azīz, studied by Muḥammad bin 'Ali al-Najjār, Vol. 1 (Cairo: al-Majlis al-A'la li al-Shuūn al-Islāmiyah, 1996), p. 134.

${ }^{7}$ Ibn 'Āshūr, Muḥammad al-Ṭāhir, al-Taḥrīr Wa al-Tanwīr, Vol. 1 (Tunis: Al-Dār alTūnisiyah, 1984), p. 201. 
Translation:

"Verily, Allah is not ashamed to set forth a parable even of a mosquito or so much more when it is bigger (or less when it is smaller) than it. And as for those who believe, they know that it is the truth fom their Lord, but as for those who disbelieve, they say: "What did Allah intend by this parable?" By it He misleads many, and many He guides thereby. And He misleads thereby only those who are Al-Fasiqun (the rebellious, disobedient to Allah)."

\section{The Type of Query:}

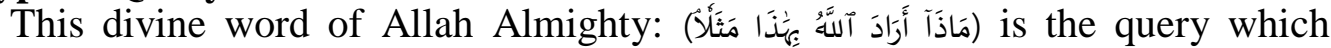
means "What Allah intends by this similitude?"

Addressing the type of query in this verse and the purpose of it, AlZamakhshari explained:

"This query not for the sake of seeking for the answer, but the purpose of it is merely to insult and degrade the Qur'an. If the Qur'an truly is the Divine Word of Allah revealed to Muhammad, the flies, spiders and alike, which are the insignificant creatures supposedly not mentioned in the Quran."

\section{Explanation:}

According to unbelievers, there are some parables in the Quran referring to insects which are the insignificant creature. One of these compares unbelievers to spiders: "Those who take beings other than God for their protectors are like a spider which makes for itself a house. The frailest of all houses is the spider's house. Could they only understand." (29:41) Similarly, the Quran cites a parable showing the powerlesness of their false deities: " $O$ mankind! A similitude has been coined, so listen to it (carefully): Verily those on whom you call besides Allah can not create (even) a fly, even though they combine together for the purpose. And if the fly snatches away a thing frrom them, they will have no power to release it fom the fly. So weak are (both) the seeker and the sought." (22:73)

This passage suggests that the hypocrites in Madinah, and probably the Jews and the polytheists, were, in their clumsy and confused campaign against Islam, trying to exploit such use of parables to raise doubts about the Qur'an's divine origins, claiming that God would not speak about such insignificant creatures as spiders and flies. They thus hoped to undermine the authority and authenticity of the Qur'an. These verses serve to refute that argument and explain the wisdom underlying the use of such parables, while warning unbelievers against taking up such a line of argument and reassuring believers that they will strengthen their faith.

"God does not disdain to give a parable of a gnat, or a higher creature." (Verse 26) God is the Lord of all creatures, big and small. Every single creature, regardless of shape or size, is a marvel to behold, embodying the greatest secret of life, which is known only to God. Besides, parables are used to explain and illustrate

${ }^{8}$ Al-Khilali, Muhammad Taqiuddin \& Muhammad Muhsin Khan, Translation the Meanings of The Noble Quran In The English Language. (Madinah: King Fahd Complex For The Printing Of The Holy Quran, 1404 H), p. 7.

${ }^{9}$ Al-Zamakhshari, Mahmud bin Amru ( $3^{\text {rd }}$ edition), Al-Kasshāf 'An Haqāiq Ghawāmid alTanzīl, Vol. 1 (Beirut: Dār al-Kitāb al- ${ }^{`}$ Arabi, 1407 H), p. 117. 
Muhammad Widus Sempo, Norita Binti Md Norwawi, Hasyim Haddade, Yousuf Mahbubul Islam, Noorhayati Binti Hasyim
Unbelievers' Mental Model and Behavioural Disorders Based on Their Queries in The Al-

Baqarah Chapter

concepts and ideas, and the size or shape of their subjects is irrelevant; in no case should they be slighted or scoffed at. Moreover, God, in His infinite wisdom, makes use of such parables to assess and test people e's faith. "Those who believe know that it is the truth from their Lord..." (Verse 26).

\section{Unbeliever's Mental and Behavioural Disorders:}

Below are the shapes of the unbeliever's mental based on their query above and the purpose of it:

1. Unbelievers are sick mentally. They are against the Quran. They are always waiting for a chance to insult and degrade the Quran.

2. They cannot realise the infinite wisdom behind the parables of Quran involving the creatures like flies, spider and mosquito. Their worldview towards the purpose of creation is very narrow-minded and biased.

3. Moreover, they ask not for the seeking of knowledge, but for insulting the values of Islam. In short, their statements substantially hatred the Quran.

\section{THE SECOND VERSE}

Allah says in the Al-Baqarah chapter, verse 28-29:

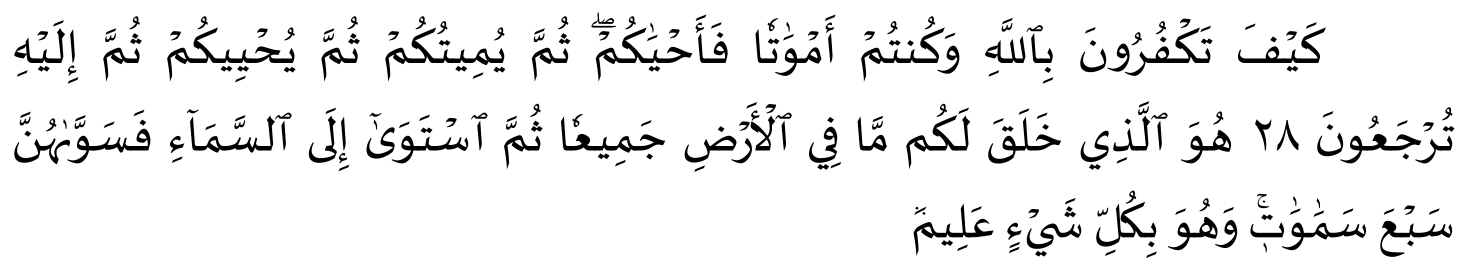

Translation:

"How can you disbelieve in Allah? Seeing that you were dead and He gave you life. Then He will give you death, then again will bring you to life (on the Day of Resurrection) and then unto Him you will return. He it is Who created for you all that is on earth. Then He rose over (istawa) towards the heaven and made them seven heavens and He is the All-Knower of everything. "11

\section{The Type of Query:}

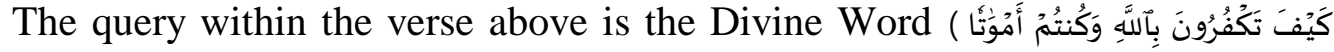

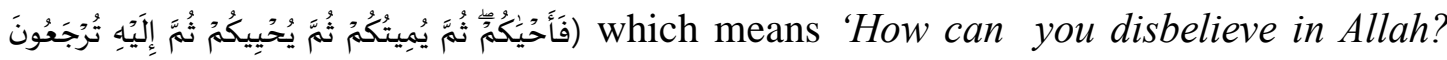
Seeing that were dead and He gave you life. Then He will give you death, then again will bring you to life (on the Day of Resurrection) and then unto Him you will return.'

The query categorized as istifhām inkāri issued by Allah towards unbelievers, which means that the Almighty God is not looking for the answer, but to deny their disbelief. The question, in other words, could be formed as follows:

What is the main reason behind their disbelief? 2015), p. 41.

${ }^{10}$ Sayyid Quṭb, Fi Zilāl Al-Quran, Vol. 1 (Markfield, United Kingdom: Islamic Foundation,

${ }^{11}$ Al-Khilali, Muhammad Taqiuddin \& Muhammad Muhsin Khan, Translation the Meanings of The Noble Quran In The English Language, p. 7. 
Why are they so fearless to deny the existence of Allah SWT, which is so clear? ${ }^{12}$

\section{Explanation:}

Verse 28 begins by expressing surprise at those who insist on being ungrateful to Allah. Then, the verse reminds man that once he was dead or that he had no life, $\mathrm{He}$ existed, if at all, in the shape of billions of lifeless particles aimlessly floating; Allah brought them together made them into a man, and gave them life.

Allah testifies to the fact that $\mathrm{He}$ exists and that $\mathrm{He}$ is the Creator and the Sustainer Who has full authority over His servants, How can anyone deny Allah's existence or worship others with Him while You did not exist beforehand. You were nothing until Allah created you; He will bring death to you and then bring you back to ${ }_{14}$ life during Resurrection. Therefore, the unbelievers and the hypocrites are the losers.

\section{Unbeliever's Mental And Behavioural Disorders:}

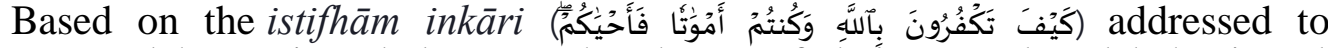
unbelievers and hypocrites, below are the shapes of their mental and behavioural disorders:

1. The unbelievers are misguided because they cannot see the actual evidence of Allah spreading everywhere on this earth.

2. They have forgotten that they were created out of nothing. Accordingly, they have no reason for disbelief in Allah. Thus, Allah faced them with the strong query as follows, "Why can you deny the existence of Allah, seeing that you were dead and He gave you life?"

3. Their quality of life is nothing to mention. They are against the truth and seeking always enmity with God. Accordingly, they denied whatever truth coming to knock their heart without having time to test the truth.

\section{The Third Verse}

Allah says in the Al-Baqarah chapter, verse 114:
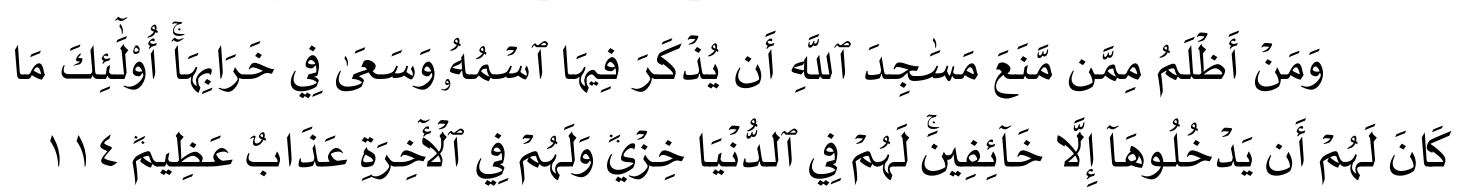

Translation:

"And who are more unjust than those who forbid that Allah's name be glorified and mentioned much (i.e. prayers and invocations, etc.) in Allah's mosques and strive for their ruin? It was not fitting that such should

${ }^{12} \mathrm{Ibn}$ 'Āshūr, al-Taḥrīr Wa al-Tanwīr, Vol. 1, p. 155.

${ }^{13}$ Muhammad Shafi', Ma ariful Quran. Translated by Prof Muhammad Hasan Askari and Prof Muhammad Shamim (No publisher and date), p. 155.

${ }^{14}$ Ibn Kathīr, Ismāēil bin 'Umar, Tafsīr al-Quran al-'Azīm (online tafsir). http://www.qtafsir.com/index.php?option=com_content\&task=view\&id=3137. Accessed on 15 September 2020. 
Muhammad Widus Sempo, Norita Binti Md Norwawi, Hasyim Haddade, Yousuf Mahbubul Islam, Noorhayati Binti Hasyim
Unbelievers' Mental Model and Behavioural Disorders Based on Their Queries in The AlBaqarah Chapter

themselvers enter them (Allah's mosques) except in fear. For them there is disgrace in this world, and they will have a great torment in the hereafter." 15

\section{The Type of Query:}

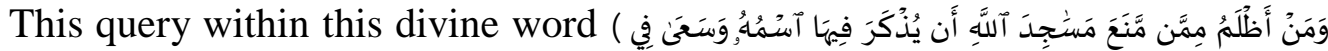
(خَرَاِكَاَّا damage Allah's mosques, either they block people from praying or destroy the mosques. ${ }^{16}$ The query formed in this verse not to looking answer, but to abuse people who prevent people from praying in the mosques.

\section{Explanation:}

This verse revealed down to admonish the polytheists of Arab as Ațā' narrated from Ibn 'Abbās. It designates people of Mekah who ban the Prophet Muhammad and the Moslems from entering Mekah as $\mathrm{Sa}^{\mathrm{e}} \mathrm{ad}$ bin $\mathrm{Mu}^{\mathrm{e}} \mathrm{a} \mathrm{dh}$ narrated when entering Mekah silently and facing Abu Jahal who scolded him, "How pity you are, you are no longer secured to perform Tawaf around the Kaaba. You all Moslems are the weakness people." It was in the year of Hudaibiyah. ${ }^{17}$

The verse may also refer to the polytheists of Romanian. As for the polytheist of Mekah, they forbade people to glorify Allah in Kaaba (the sanctified house of Allah) and blocked people to visit the Messenger of Allah and his companions in Mekah as practised before by the polytheists of Romanian who struggle to destroy Bayt Al-Maqdis (Jerusalem). Both are in the same quality of having ungentlemanly behaviour.

Accordingly, the Moslems supposedly strive in blocking the polytheists and unbelievers to conquer our islands, including the mosques. Otherwise, we still experience the same problem as the past of being blocked to perform any Islamic rituals in mosques. ${ }^{19}$

\section{Unbeliever's Mental And Behavioural Disorders:}

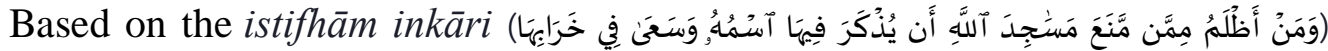
addressed to unbelievers and polytheists of Mekah, they don't respect the value of the mosques as the sacred place for Moslems to do prayer and glorify Allah. Besides, they do not understand that the mosques just one place for Moslems to worship Allah. Other than that, the earth is a place for Moslem to do the prayer. Accordingly, it is

${ }^{15}$ Al-Khilali, Muhammad Taqiuddin \& Muhammad Muhsin Khan, Translation the Meanings of The Noble Quran In The English Language, p. 22.

${ }^{16} I b n ' \bar{s}$ shūr, Muḥammad al-Ṭāhir, al-Taḥrīr Wa al-Tanwīr, Vol. 1, p. 678-679.

${ }^{17}$ Ibid.

${ }^{18}$ Muḥammad 'Abduh \& Rashīd Riḍā, Tafsīr al-Manār, Vol. 1 (Egypt: Al-Haeah al-Mișriyah al- 'Ammah li al-Kitāb, 1990), p. 354.

${ }^{19}$ Nawawi al-Bantani, Muhammad bin ${ }^{~} U m a r\left(1^{\text {st }}\right.$ edition), Marāh Labīd Li Kashf Ma'āni AlQur'an al-Majīd. Studied by Muḥammad al-Sanāwi, $1^{\text {st }}$ edition, Vol. 1 (Beirut: Dār al-Kutub al'Ilmiyyah, 1417 H), p. 40. 
Unbelievers' Mental Model and Behavioural Disorders Based on Their Queries in The AlBaqarah Chapter
Muhammad Widus Sempo, Norita Binti Md Norwawi, Hasyim Haddade, Yousuf Mahbubul Islam, Noorhayati Binti Hasyim

unjust to destroy the mosques because of hatred to Moslems. Thus, they should take their self away from abusing Islam and the Moslems after considering that Allah prepares for them great torture in the hereafter. Unluckily, they do not obey this warning and strive to ruin the mosques. It is the shapes of unbeliever's mental and behavioural disorders understood through the above verse.

\section{THE FOURTH VERSE:}

Allah says in the Al-Baqarah chapter, verse 142:

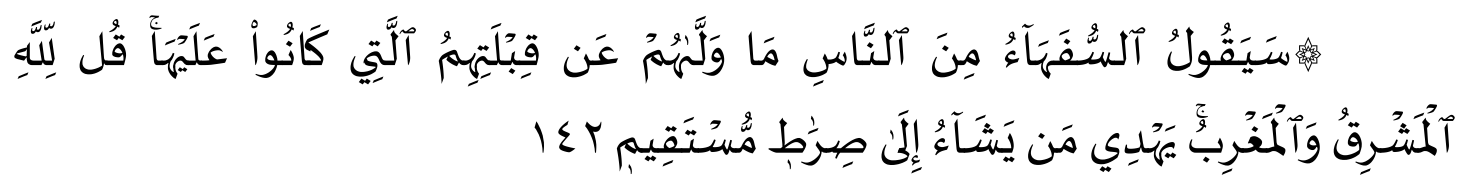

Translation:

"The fools among the people (pagans, hypocrites, and jews) will say, "What has turned them (Moslems) from their Qiblah (prayer direction towards Jerusalem (Bayt al-Maqdis) they used to face in prayer." Say, (O Muhammad peace be upon him), "To Allah belong both, east and the west. He guides whom He wills to the straight path." 20

\section{The Type of Query:}

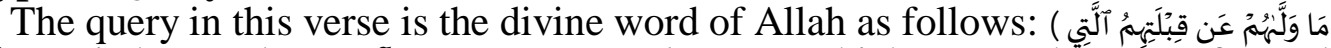

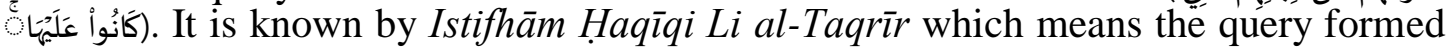
to seek an answer for what happened. The story is about the changing of Qiblah of Moslem in prayer. Before going to have another Qiblah, which is the Kaaba, the Moslems faced Bayt al-Maqdis (Jerusalem). Therefore, the unbelievers examined the reason for this changing. ${ }^{21}$

\section{Explanation:}

According to Ibn 'Atiyyah, the foolish among the people mentioned in the verse are jews, hypocrites and unbelievers of Quraish in Mekah. They kept seeking the answer for changing direction in prayer from Jerusalem to the Kaaba. They asked the Messenger of Allah (peace be upon him) to turn back to Jerusalem in prayer. The Kaaba, according to them, has no much meaning of spirituality compared to Bayt alMaqdis (Jerusalem), the place of many prophets and messengers. ${ }^{2}$

Al-Zamakshari threw the question, "What benefit of acknowledging their attitude towards changing of direction in prayer before this matter happens?"

${ }^{20}$ Al-Khilali, Muhammad Taqiuddin \& Muhammad Muhsin Khan, Translation the Meanings of The Noble Quran In The English Language, p. 29.

${ }^{21}$ Abu Hayyān al-Andalusi, Muḥammad bin Yūsuf bin 'Ali, Al-Baḥru al-Muḥịt fi al-Tafsīr. Studied by Șidqi Muḥammad Jamīl, Vol. 2 (Beirut: Dār al-Fikr, 1420 H), p. 10.

${ }^{22}$ Ibn Aṭiyyah, `Abd al-Ḥaq bin Ghālib (1 ${ }^{\text {st }}$ edition), al-Muḥarrar al-Wajīz Fi Tafsīr Al-Kitāb al-HAzz̄z, studied by 'Abd al-Salām 'Abd al-Shāfi Muḥammad, Vol. 1 (Beirut: Dār al-Kutub Al'Ilmiyah, 1422 H), p. 217. 
Muhammad Widus Sempo, Norita Binti Md Norwawi, Hasyim Haddade, Yousuf Mahbubul Islam, Noorhayati Binti Hasyim
Unbelievers' Mental Model and Behavioural Disorders Based on Their Queries in The Al-

Al-Zamakhsari said, "it was to prepare the Moslems in facing this kind of attitude from the enemies of Islam when the changing of Qiblah happens. So, they are ready mentally to face any kind of abuses expected from those people." ${ }^{2} 3$

According to Sayyid Quṭb, the enemies of Islam, including Jews, polytheists of Mekah and hypocrites tried to exploit the Qiblah issue to create division and confusion among the Moslems. They began to question the wisdom of the Muslim leadership and to raise doubts about the validity of the religious basis of Islam. Did the change of qiblah from Jerusalem to the Ka bah mean that the Muslims had been praying towards the wrong qiblah all that time? And, if Jerusalem was the right qiblah, and it was correct to face it in the prayer, then it must have been wrong to change to another one. Praying towards the new qiblah, the Kaaba, would, in this case, not be valid. They further argued that such abrogation of earlier orders could not be done by God. Hence, the decision must have been made by Muhammad himself, proving that he was not receiving any divine revelations.

The Jews ignored that Muhammad had a strong desire that God might direct him to a Kaaba, a house that's built by his ancestor, Prophet Ibrahim. The divine decree, expressed here with compassion and love, comes in line with the Prophet's wish. The new direction of prayer is exactly the one he has been silently hoping for all those months: "We shall, therefore, make you turn in prayer towards a direction you will be happy with. Turn your face, then, towards the Sacred Mosque." (Verse 144) What is more, is that it is a permanent and universal one: "Wherever you all may be, turn your faces [in prayer] towards it." (Verse 144).

\section{Unbeliever's Mental And Behavioural Disorders:}

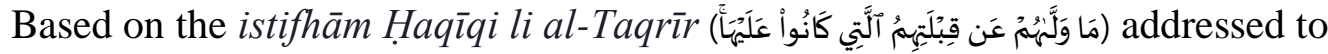
Jews, hypocrites and polytheists of Mekah, below are the shapes of their mental and behavioural disorders:

1. The jews, the hypocrites and the polytheists of Mekah are senseless. They used to seek a chance to create any controversy about Islam. For example, the controversy about the change of Qiblah from Jerusalem to Makkah conceived by the Jews in Madinah and followed by hypocrites in Madinah and polytheists of Mekah.

2. Those people are against Islam. They don't stop fabricating the fake issue related to Islam until the Moslem follows them. They have a high skill in manipulating the fact and conceiving the fraudulent issue.

\section{THE FIFTH VERSE:}

Allah Says in the Al-Baqarah chapter, verse:210:

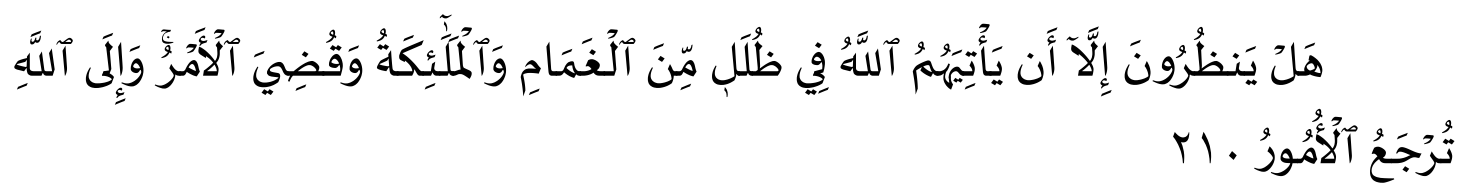

\footnotetext{
${ }^{23}$ Al-Zamakhshari, Al-Kasshāf, Vol. 1, p. 197.

${ }^{24}$ Sayyid Quṭb, Fi Zilāl Al-Quran, Vol. 1, p. 142.

${ }^{25}$ Ibid, Vol. 1, p. 152.
} 
Translation:

"Do they then wait for anything other than that Allah should come to them in the shadow of the clouds and the angels? (Then) the case would be ready judged. And to Allah return all matters (for decision)."

\section{The Type of Query:}

(هَلْل) is the query tool to query the unbelievers about their reason in denying

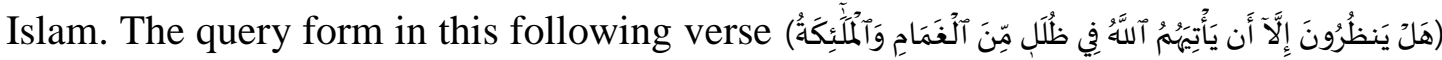
known by Istifhām Haqiqqi (the real query) which functioned here to seek the real reason of unbelievers in rejecting Islam. ${ }^{27}$

\section{Explanation:}

This query refers to those who refused to convert into Islam. The punishment of Allah awaited for them together with a storm cloud. Besides, there is the angel that already assigned exclusively to punish them at that moment.

To whom denied converting Islam, they have nothing waiting for them after the proofs of Allah revealed down to them except the hereafter that Allah appears in the clouds to punish them at the moment.

In detail, Al-Sabuni (1997:1/120) says as follows:

"The unbelievers have nothing to be waiting for except the hereafter when

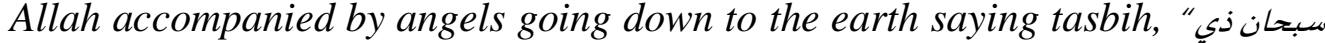

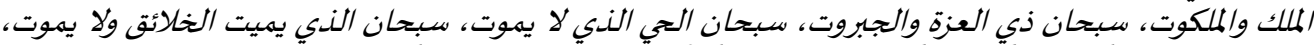
"سبوح قدوس وب المالائكة والروح of the doom day and its severity. Furthermore, the verse also goes to explain that the ruler at that time is the king of kings, the Almighty God. He is the wisest rulers and nobody could deny His judiciary.

In terms of the punishment hat comes down from the cloud, Al-Zamakhshari says:

${ }^{26}$ Al-Khilali, Muhammad Taqiuddin \& Muhammad Muhsin Khan, Translation the Meanings of The Noble Quran In The English Language, p. 44.

${ }^{27}$ Ibn 'Āshūr, Muhammad al-Ṭāhir, al-Taḥrīr Wa al-Tanwīr, Vol. 2, p. 282.

${ }^{28}$ Al-Wāḥidi, 'Ali bin Aḥmad bin Muḥammad, (1 $1^{\text {st }}$ edition), al-Wajīz Fi Tafsīr Al-Kitāb al'Aż̄z. Tahkik Șafwān 'Adnān Dawūdi (Beirut: Dār al-Qalam, 1415 H), p. 160.

${ }^{29}$ Ṭanțāwi, Muhammad Sayyid, (1 ${ }^{\text {st }}$ edition), al-Tafsīr al-Wasīt, Vol. 1 (Cairo: Dār Nahḍah, 1997), p. 450.

${ }^{30}$ Al-Ṣābūni, Muhammad 'Ali (1 ${ }^{\text {st }}$ edition), Șafwah al-Tafāsīr, Vol. 1 (Cairo: Dār al-Ṣābūni, 1997), p. 120. 
Muhammad Widus Sempo, Norita Binti Md Norwawi, Hasyim Haddade, Yousuf Mahbubul Islam, Noorhayati Binti Hasyim
Unbelievers' Mental Model and Behavioural Disorders Based on Their Queries in The Al-

"Why do they suffer in the clouds? Because the cloud is a sign of mercy. If the punishment comes down from the sky, the matter is going to be shocked and very scared." 31

\section{Unbeliever's Mental And Behavioural Disorders:}

1. Unbelievers begged more time to embrace Islam, but the time they are looking for is not coming. They didn't believe in hereafter at all because it is a matter of metaphysical all about that science couldn't prove it.

2. A blocked mentality towards Islam is the most problem faced by unbelievers. They closed the eyes towards Islam, even the truth of Islam very clear. This is the cowardly mentality of the infidels faced by Moslems society from time to time.

\section{Conclusion}

Most of the queries of the disbelievers in the Al-Baqarah chapter are to disparage Islam. Their query not to seek an answer but lower the dignity of Moslems. On the other hand, most of Allah's queries directed at unbelievers are in the form of denial and amazement (inkāri wa ta'ajjubi). Allah rebuked them with harsh corrections for stubbornly living in disbelief. However, they do not concede and hold solid to the faith of their ancestors. They despise Islam, Muhammad, and Moslems. Their heart and soul is sick. Therefore, they want to destroy Islam and make it no longer exist on this earth.

Likewise is the personality of the unbelievers described in the Qur'an in general and in the Al-Baqarah chapter in particular.

Most of their questions to ridicule Islam are related to the faith, prophethood, hereafter and Islamic jurisprudence. The Prophet (Peace be Upon Him) sometimes did not know the evil intentions behind their query. Thus, Allah guided directly His beloved Messenger (Peace be Upon Him) how to answer this kind of question. For example, when the infidels mocked the Prophet SAW when changing the qibla of Muslims from Bayt Al-Maqdis (Jerusalem) to the Kaaba in Mekah by saying, "What has turned them (Moslems) from their Qiblah (prayer direction towards Jerusalem (Bayt al-Maqdis) they used to face in prayer?" Allah directly guided His Messenger (Peace be Upon Him) to reply to them a proper answer by saying, "O Muhammad peace be upon him), "To Allah belong both, east and the west. He guides whom $\mathrm{He}$ wills to the straight path."

\section{E. Acknowledgement}

This paper presents a work that is supported by a research collaboration between DAFFODIL INTERNATIONAL UNIVERSITY and UNIVERSITI SAINS ISLAM MALAYSIA (USIM), coded by USIM/MG/DAFFODIL/ISI/055012/70618, by title: Technology Supported Inquiry Instructional Model From Al-Quran For Islamic Science.

\footnotetext{
${ }^{31}$ Al-Zamakhshari, Al-Kasshāf, Vol. 1, p. 253.
} 
Unbelievers' Mental Model and Behavioural Disorders Based on Their Queries in The AlBaqarah Chapter
Muhammad Widus Sempo, Norita Binti Md Norwawi, Hasyim Haddade, Yousuf Mahbubul Islam, Noorhayati Binti Hasyim

\section{BIBLIOGRAPHY}

Al-Quran Al-Karim, (4 ${ }^{\text {th }}$ edition), (Selangor: Ultimate Print. SDN. BHD, 2017).

Abu Ḥafṣ al-Nu 'māni, 'Umar bin 'Ali bin 'Ādil, (1st edition), al-Lubāb di 'Ulūm alKitāb, studied by 'Ādil Aḥmad 'Abd al-Mawjūd (Beirut: Dār al-Kutub al'Ilmiyyah, 1998).

Abu Hayyān al-Andalusi, Muḥammad bin Yūsuf bin 'Ali, Al-Bahru al-Muhīt fi alTafsīr. Studied by Șidqi Muḥammad Jamīl, Vol. 2 (Beirut: Dār al-Fikr, 1420 $\mathrm{H})$.

Abu Zuhrah, Muhammad bin Aḥmad bin Mușțafa, Zuhrat al-Tafāsīr, Vol. 1 (Beirut: Dār al-Fikr al-'Arabi), p. 484

Al-Fayruzabādi, Muhammad bin Ya'qūb, Bașā̄r Dhawi al-Tamyīz fi Lațāif al-Kitāb al-'Azīz, studied by Muḥammad bin 'Ali al-Najjār, (Cairo: al-Majlis al-A' la li al-Shuūn al-Islāmiyah, 1996).

Al-Khilali, Muhammad Taqiuddin \& Muhammad Muhsin Khan, Translation the Meanings of The Noble Quran In The English Language. (Madinah: King Fahd Complex For The Printing Of The Holy Quran, 1404 H).

Al-Nawawi Al-Nawawi, Yahya bin Sharaf, Sharh al-Nawawi 'Ala Muslim (Beirut: Dar Iḥyā' al-Turāth al-'Arabi: 1392 H)

Al-Ṣābūni, Muḥammad 'Ali ( $1^{\text {st }}$ edition), Șafwah al-Tafāsīr (Cairo: Dār al-Ṣābūni, 1997).

Al-Wāḥidi, 'Ali bin Aḥmad bin Muḥammad, (1 ${ }^{\text {st }}$ edition), al-Wajīz Fi Tafsīr Al-Kitāb al- 'Azìz. Tahkik Șafwān `Adnān Dawūdi (Beirut: Dār al-Qalam, 1415 H).

Al-Zamakhshari, Mahmud bin Amru (3 ${ }^{\text {rd }}$ edition), Al-Kasshāf 'An Haqāiq Ghawāmị al-Tanzīl (Beirut: Dār al-Kitāb al- 'Arabi, 1407 H).

Council for Ecxeptional Childrem, Behavior Disorders: Definitions, Characteristics \& Related Information. https://community.cec.sped.org/ccbd/about/ebddefintion. Accessed on 28 Sept 2020.

Difference Between.net, Difference Between Onquiry and Query. http://www.differencebetween.net/language/words-language/differencebetween-inquiry-and-query/. Accessed on 28 Sept 2020.

Ibn 'Āshūr, Muḥammad al-Ṭāhir, al-Taḥrīr Wa al-Tanwīr (Tunis: Al-Dār alTūnisiyah, 1984). 
Muhammad Widus Sempo, Norita Binti Md Norwawi, Hasyim Haddade, Yousuf Mahbubul Islam, Noorhayati Binti Hasyim
Unbelievers' Mental Model and Behavioural Disorders Based on Their Queries in The AlBaqarah Chapter

Ibn Kathīr, Ismāēil bin 'Umar, Tafsīr al-Quran al-'Azīm (online tafsir). http://www.qtafsir.com/index.php?option=com_content\&task=view\&id=3137. Accessed on 15 September 2020.

Ibn țAṭyyah, 'Abd al-Haq bin Ghālib (1 ${ }^{\text {st }}$ edition), al-Muharrar al-Wajīz Fi Tafsīr Al-Kitāb al-HAzīz, studied by 'Abd al-Salām 'Abd al-Shāfi Muḥammad (Beirut: Dār al-Kutub Al- 'Ilmiyah, 1422 H).

Mental Health.gov, What is Mental Health? https://www.mentalhealth.gov/basics/what-is-mental-health. Accessed on 30 September 2020

Muhammad 'Abduh \& Rashīd Riḍā, Tafsīr al-Manār (Egypt: Al-Haeah al-Miṣriyah al-'Ammah li al-Kitāb, 1990).

Muhammad bin Aḥmad bin Ismāê̄l, (6 ${ }^{\text {th }}$ edition), Fiqh Ashrāt al-Sā'a $\bar{h}$ (al-Dār al'Ālamiyah, 2008).

Muhammad Shafi', Ma'ariful Quran. Translated by Prof Muhammad Hasan Askari and Prof Muhammad Shamim (No publisher and date).

Nawawi al-Bantani, Muhammad bin 'Umar ( $1^{\text {st }}$ edition), Marāh Labīd Li Kashf Ma'āni Al-Qur'an al-Majīd. Studied by Muhammad al-Sanāwi, $1^{\text {st }}$ edition (Beirut: Dār al-Kutub al- 'Ilmiyyah, 1417 H).

Sayyid Quțb, Fi Zilāl Al-Qura (Markfield, United Kingdom: Islamic Foundation, 2015).

Ṭanțāwi, Muhammad Sayyid, (1 ${ }^{\text {st }}$ edition), al-Tafsīr al-Wasịt (Cairo: Dār Nahḍah, 1997).

Tayseer K. Ibrahim, "Rulings of Mocking Prophet Mohammed Peace Be Upon Him (PBUH) ”, Journal of Islamic Study, Vol. 24, No. 1(2016). 


\section{Guidelines}

\section{Submission of Article}

urnal Adabiyah welcomes the articles submission with the main themes on Humanities and Islamic Studies with the emphasis on interdisciplinary and intertextuality approach. Adabiyah is thematicly published twice in a year. ie the theme of the humanities in June and the Islamic Study in December.

Themes related to Islamic Studies are textual studies, scriptural traditions, Islamic law, and theology; and those related to Humanities are language, literature, history, and culture. This scholarly journal Guarantees that the editor decision based on the peer review results will not exceed 30 days from the paper submission date.

Authors are invited to read our archives; to find the relevant topics for the journal, and to submit complete unpublished scientific researches, which are not under review in any other conferences or academic journal.

\section{PUBLICATION ETHIC}

Publication Ethic and Malpractice Statement

Jurnal Adabiyah is a peer-reviewed journal, published twice a year by the Faculty of Adab and Humaniora, Alauddin State Islamic University of Makassar Indonesia. It is available online as open access sources as well as in print. This statement clarifies ethical behaviour of all parties involved in the act of publishing an article in this journal, including the author, the editor-in-chief, the Editorial Board, the reviewers, and the publisher. This statement is based on COPE's Best Practice Guidelines for Journal Editors.

Ethical Guideline for Journal Publication

The publication of an article in Jurnal Adabiyah, is an essential building block in the development of a coherent and respected network of knowledge. It is a direct reflection of the quality of the work of the authors and the institutions that support them. Peer-reviewed articles support and embody the scientific methods. It is therefore important to agree upon standards of expected ethical behavior for all parties involved in the act of publishing: the author, the editor, the reviewer, the publisher, and the society. As the publisher of Jurnal Adabiyah, the Faculty of Adab and Humaniora takes its duties of guardianship over all stages of publishing seriously and it recognizes its ethical and other responsibilities. The Faculty of Adab and Humaniora committed to ensuring that advertising, reprint or other commercial revenue has no impact or influence on editorial decisions.

\section{Publication Decisions}

The editors of Jurnal Adabiyah is responsible for deciding which articles submitted to the journal should be published. The validation of the work in question and its importance to researchers and readers must always drive such decisions. The editors may be guided by the policies of the journal's editorial board and constrained by such legal requirements as shall then be in force regarding libel, copyright infringement, and plagiarism. The editors may confer with other editors or reviewers in making their decisions.

\section{Plagiarism Screening}

It is basically author's duty to only submit a manuscript that is free from plagiarism and academically malpractices. The editor, however, will check all submitted papers through Turnitin.

\section{Fair Play}

An editor at any time evaluates manuscripts for their intellectual content without regard to race, gender, sexual orientation, religious belief, ethnic origin, citizenship, or political philosophy of the authors. 


\section{Confidentiality}

The editors and any editorial staff must not disclose any information about a submitted manuscript to anyone other than the corresponding author, reviewers, potential reviewers, other editorial advisers, and the publisher, as appropriate.

\section{Disclosure and Conflicts of Interest}

Unpublished materials disclosed in a submitted manuscript must not be used in editors' own research without the express written consent of the author.

\section{DUTIES OF AUTHORS}

\section{Reporting Standards}

Authors of reports of original research should present an accurate account of the work performed as well as an objective discussion of its significance. Underlying data should be represented accurately in the paper. A paper should contain sufficient detail and references to permit others to replicate the work. Fraudulent or knowingly inaccurate statements constitute unethical behaviour and are unacceptable.

\section{Originality and Plagiarism}

The authors should ensure that they have written entirely original works, and if the authors have used the work and/or words of others that this has been appropriately cited or quoted.

\section{Multiple, Redundant, or Concurrent Publication}

An author should not in general publish manuscripts describing essentially the same research in more than one journal or primary publication. Submitting the same manuscript to more than one journal concurrently constitutes unethical publishing behaviour and is unacceptable.

\section{Acknowledgement of Sources}

Proper acknowledgment of the work of others must always be given. Authors should cite publications that have been influential in determining the nature of the reported work.

\section{Authorship of the Paper}

Authorship should be limited to those who have made a significant contribution to the conception, design, execution, or interpretation of the reported research. All those who have made significant contributions should be listed as co-authors. Where there are others who have participated in certain substantive aspects of the research project, they should be acknowledged or listed as contributors. The corresponding author should ensure that all appropriate co-authors and no inappropriate co-authors are included on the paper, and that all co-authors have seen and approved the final version of the paper and have agreed to its submission for publication.

\section{Disclosure and Conflicts of Interest}

All authors should disclose in their manuscript any financial or other substantive conflict of interest that might be construed to influence the results or interpretation of their manuscript. All sources of financial support for the project should be disclosed.

\section{Fundamental errors in Published Works}

When an author discovers a significant error or inaccuracy in his/her own published work, it is the author's obligation to promptly notify the journal editor or publisher and cooperate with the editor to retract or correct the paper.

\section{PLAGIARISMIE}

It is basically author's duty to only submit a manuscript that is free from plagiarism and academically malpractices. The editor, however, will check all submitted papers through Turnitin. 


\section{AUTHOR GUIDELINES}

\section{Guidelines for online submission:}

1. Author should first register as Author to the website of Jurnal Adabiyah. Click the menu "register" to register as an author.

2. Once after the author is registered, please login to the website of Jurnal Adabiyah and submit the article through online submission (with the stat us of active submissions).

3. The article should follow the standard template of Jurnal Adabiyah provided in the website.

4. The citation and bibliography should follow the Turabian citation style.

5. Author is restricted not to send his/her article to another journal before having confirmation from the editorial team (approximately 4 weeks right after the article submitted).

6. Author should follow editorial decisions and recommendations related to the article completion. All reviews and assessements will be informed through online submission.

Article submitted to Jurnal Adabiyah editorial board must follow these guidelines:

1. Article should be based on the scientific research in the field humanities and Islamic studies;

2. Article must be an original work and has not been previously published;

3. Article should be written in Arabic or English languages;

4. Article must be typed in one-half spaced on A4-paper size;

5. Article's length is about $6,000-10,000$ words;

6. All submission must include a 150-250 word abstract;

7. Abstract should be written in 3 languages; Arabic, English, and Bahasa;

8. Full name(s) of the author(s) must be stated, along with his/her/their institution and complete address;

9. All submission should be in OpenOffice, Microsoft Word, RTF, or WordPerfect document file format;

10. Bibliographical reference must be noted in footnote and bibliography according to Jurnal Adabiyah style. In addition, it is suggested for author(s) to use reference manager tools such

\section{as MENDELEY or 7 otero}

When a source is cited for the first time, full information is provided: full name(s) of author(s), title of the source in italic, place of publication, publishing company, date of publication, and the precise page that is cited. For the following citations of the same source, list the author's last name, two or three words of the title, and the specific page number(s). The word ibid., op.cit., and loc.cit. are may not be used any more.

\section{Example in footnotes:}

${ }^{1}$ Mircea Eliade (ed.), The Encyclopedia of Religion, vol. 8 (New York: Simon and Schuster, 1995), h. 18.

${ }^{2}$ Norman Daniel, Islam and the West (Oxford: One World Publications, 1991), h. 190.

${ }^{3}$ Syeikh Ja'far Subhāni, Mafăhim Al-Qur'ān (Beirut: Mu'assasah Al-Tarīkh Al-'Arabī, 2010)., Juz 5, h. 231. 
${ }^{4}$ Syeikh Ja'far Subhānī, Mafāhim Al-Qur'ān, h. 8-9.

\section{Example in bibliography:}

Subhānī, Syeikh Ja'far. Mafăhim Al-Qur'ān. Beirut: Mu'assasah Al-Tarīkh Al-’Arabī, 2010.

Eliade, Mircea (ed.). The Encyclopedia of Religion, vol. 8. New York: Simon and Schuster, 1995.

Daniel, Norman. Islam and the West. Oxford: One World Publications, 1991.

Shihab, Muhammad Quraish. Sunnah-Syiah Bergandengan Tangan: Mungkinkah? Kajian Atas Konsep Ajaran Dan Pemikiran. Cet. III. Jakarta: Lentera Hati, 2007.

\section{Detail informations of the footnotes:}

1. Holy book

Al-Qur'ân, Al-Baqarah/2: 185.

Perjanjian Baru, Mrk. 2: 18.

2. Qur'anic translation

${ }^{1}$ Departemen Agama RI, al-Qur'an dan Terjemahannya (Jakarta: Darus Sunnah, 2005), h. 55.

3. Book

${ }^{1}$ Muḥammad 'Ajjaj al-Khațib, Ușl al-Hadith: 'Ulumuh wa Mușțalaḥ uh (Beirut: Dâr al-Fikr, 1989), h. 57.

4. Translation Books

${ }^{1}$ Toshihiko Izutsu, Relasi Tuhan dan Manusia: Pendekatan Semantik terhadap al-Qur'an, terj. Agus Fahri Husein dkk (Yogyakarta: Tiara Wacana, 2003), h. 14.

5. Voluminous book

${ }^{1}$ Muḥammad al-Ṭâhir b. 'Ashur, al-Tahrīir wa al-Tanwīr, Vol. 25 (Tunisia: Dâr al-Suhûn, 2009), h. 76.

${ }^{1}$ Muḥammad b. Ismā‘īl al-Bukharī, al-Jami‘ al-Ṣaḥịh, Vol. 2 (Beirut: Dar al-Kutub al-‘Ilmı́yah, 1999), h. 77.

6. Article in book

${ }^{1}$ Sahiron Syamsuddin, "Metode Intratekstualitas Muhammad Shahrur dalam Penafsiran al-Qur'an" dalam Abdul Mustaqim dan Sahiron Syamsuddin (eds.), Studi al-Qur'an Kontemporer: Wacana Baru Berbagai Metodologi Tafsir (Yogyakarta: Tiara Wacana, 2002), h. 139.

7. Article in encyclopaedia

${ }^{1}$ M. Th. Houtsma, "Kufr" dalam A. J. Wensinck, at al. (ed.), First Encyclopaedia of Islam, Vol. 6 (Leiden: E.J. Brill, 1987), h. 244.

8. Article in journal

${ }^{1}$ Muhammad Adlin Sila, "The Festivity of Maulid Nabi in Cikoang, South Sulawesi: Between Remembering and Exaggerating the Spirit of Prophet", Studia Islamika 8, no. 3 (2001): h. 9.

9. Article in mass media

${ }^{1}$ Masdar F. Mas'udi, "Hubungan Agama dan Negara”, Kompas, 7 Agustus 2002. 
10. Article in Internet

${ }^{1}$ Muhammad Shahrūr, "Reading the Religious Teks: a New Approach" dalam http://www.shahrour.org/25 Februari 2010/diakses 5 Juni 2010.

11. Thesis or dissertation

${ }^{1}$ Syahruddin Usman, "KinerjaGuru Penddikan Agama Islam pada SMAN dan SMKN Kota Makassar”, Disertasi (Makassar: PPs UIN Alauddin, 2010), h. 200.

\section{COPYRIGHT NOTICE}

Authors who publish with this journal agree to the following terms:

1) Authors retain copyright and grant the journal right of first publication with the work simultaneously licensed under a Creative Commons Attribution License that allows others to share the work with an acknowledgement of the work's authorship and initial publication in this journal.

2) Authors are able to enter into separate, additional contractual arrangements for the non-exclusive distribution of the journal's published version of the work (e.g., post it to an institutional repository or publish it in a book), with an acknowledgement of its initial publication in this journal.

3)Authors are permitted and encouraged to post their work online (e.g., in institutional repositories or on their website) prior to and during the submission process, as it can lead to productive exchanges, as well as earlier and greater citation of published work (See The Effect of Open Access). 